Research Article

Witold Wiliński*

\title{
Changes in the fiscal policy of EU states after the 2008 crisis
}

https://doi.org/10.2478/ijme-2019-0004

Received September 27, 2018; accepted December 01, 2018

\begin{abstract}
The aim of this article is an extensive presentation of the fiscal policy conducted by the EU states in the years 2008-2015. The analysis concerns the legal regulations introduced at the EU level by the European Parliament and the Council, as well as the fiscal policies of governments of particular states. The first part of the article analyzes basic macroeconomic data in EU states concerning the level of debt, the level of gross domestic product (GDP) redistribution, and the level of economic growth in the analyzed period. The second part discusses the legal acts adopted by the European Parliament and the Council (the so-called 'sixpack' and the European Fiscal Compact), aimed at improving macroeconomic balance and ensuring supervision over the proper functioning of national finances. The third part analyzes the discretionary fiscal policies pursued in EU states. The main conclusions of this article are as follows: (i) EU countries recorded higher national debt levels and debt growth rates between 2008 and 2015 than most non-EU Organisation for Economic Co-operation and Development (OECD) countries; (ii) despite legal measures taken by the European Council and the European Commission in the form of the sixpack and the European Fiscal Compact, and despite discretionary fiscal measures such as in the form of the European Economic Recovery Plan, five EU countries (Cyprus, Greece, Italy, Portugal, and Spain) have experienced a steady increase in their national debt levels; and (iii) deep reforms in the composition and level of government expenditure are a prerequisite for reducing national debt levels and for achieving satisfactory economic growth in these countries.
\end{abstract}

JEL Classification: H12 Crisis Management, H63 Debt, Debt Management, H30 General Fiscal Policy, H25 Business Taxes and Subsidies.

\section{Analysis of the economic growth rate and debt level}

Fiscal policy is a function of the economic and social objectives pursued by individual governments. The objectives affected by governments are determined by the views of the ruling parties on the role of the state in the economy. Although the axis of the disputes between the representatives of different views is different among the developed economies of North America, Asia, or Europe, there are undoubtedly common grounds in the disputes that exist in all highly developed countries. These disputes concern ways of financing the pensions, education, and healthcare systems, as well as the regulation of the labor market. Each government decision in one of these areas usually has a direct impact on state fiscal policy, one of the main objectives of which, in terms of certain simplification, is to ensure sufficient budgetary resources for the implementation of government policy. Conversely, the derivatives of these decisions concerning the level of state expenditure are budget size, the budget surplus or deficit, the level of national debt in relation to gross domestic product (GDP), and the level of inflation. These basic macroeconomic values can have an impact on the pace of economic development and are also an important tool in how economic policy is run. The manner of conducting fiscal policy is particularly important in times of economic crisis, when fiscal

*Corresponding author: Witold Wiliński, Collegium of World Economy, SGH Warsaw School of Economics, Warsaw, Poland,

E-mail: witold.wilinski@sgh.waw.pl 
stimulus is translated relatively quickly into producer and consumer behaviors. According to Trichet [2013], fiscal policy for the euro area countries (i.e. countries without the ability to run their own monetary policy, including exchange rate policy) is currently the most important tool for conducting economic policy and can effectively help in cushioning the results of external crises.

Among economists and economic politicians, the main axis of disagreement over how fiscal policy is conducted and its consequences lies between neo-classical and neo-Keynesian economics. Simply speaking, neo-classical economics is in favor of a restrictive fiscal policy, while the neo-Keynesian economics advocates that fiscal easing during an economic crisis will put the economy back on a growth path. It is worth mentioning here the work of Hebous [2009] who analyzed 21 studies on the impact of an increase in state expenditure and 11 studies on the impact of fiscal policy on the levels of consumption, employment, and interest rates in highly developed states. According to Hebous [2009], the results of studies in both of these areas are not clear and depend to a large extent on the analyzed country and period. An additional problem in this type of study is the difficulty in separating the impact of fiscal policy on the economy from other factors.

The first stage of the analysis carried out in this work is to assess the level of indebtedness of EU states in relation to GDP, the level of state expenditure in relation to GDP, and the pace of economic development. An analysis of these basic values may give some indication of the economic development before and after the crisis, as well as of the easily measurable impact of currently run fiscal policy. The macroeconomic situation of the EU states before the financial crisis of 2008, and in particular the level of indebtedness of these economies and the level of redistribution of GDP through the budgets, was the result of many years of economic policies of individual EU state governments. The gradual increase in the redistribution of GDP and the expansion of social systems during periods of economic growth have led to a situation where, in most of the old EU member states, the level of debt in relation to GDP was already higher than $60 \%$ at the start of the economic crisis and therefore higher than the convergence criteria that should be met by countries wishing to participate fully in the economic and monetary union. Moreover, average indebtedness was also higher than $60 \%$ in the euro area states, and in the case of Italy and Greece, it was already above $90 \%$ in 2007.

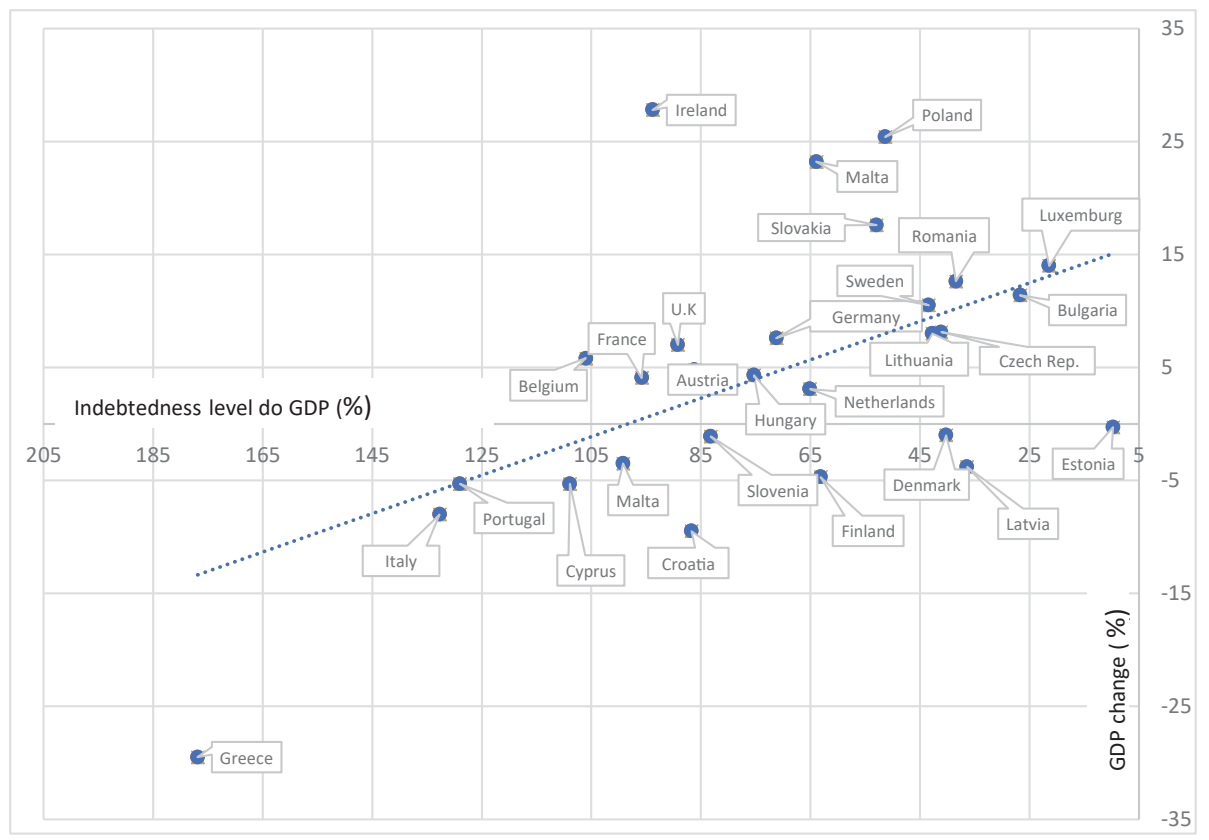

Figure 1. Indebtedness level (\%) in relation to GDP in 2015 and GDP change in 2008-2015 in EU states. Source: Own calculation based on Eurostat data [http://ec.europa.eu/Eurostat, access 18/06/2018].

Figures 1 and 2 show the indebtedness levels and budget expenditures in relation to GDP in 2015 in the EU states. In both cases, these data are shown in comparison with the GDP change in the period 2008-2015. 
Five countries (Spain, Cyprus, Portugal, Italy, and Greece) experienced negative GDP changes between 2008 and 2015. This means that these countries did not experience average annual economic growth over a period of eight years. In these countries, the debt-to-GDP ratio exceeded 99\% in 2015. The only exception among the EU states with the highest level of debt was Belgium, which achieved positive economic growth in this period despite indebtedness exceeding 99\%. The relationship between overindebtedness and its negative impact on economic growth was described by Barro [1979] on the basis of data from the United States economy from 1917 to 1976, as well as in the studies by Reinhart and Rogoff [2010] concerning the differentiated impact of debt on the economic growth in developing and highly developed countries.

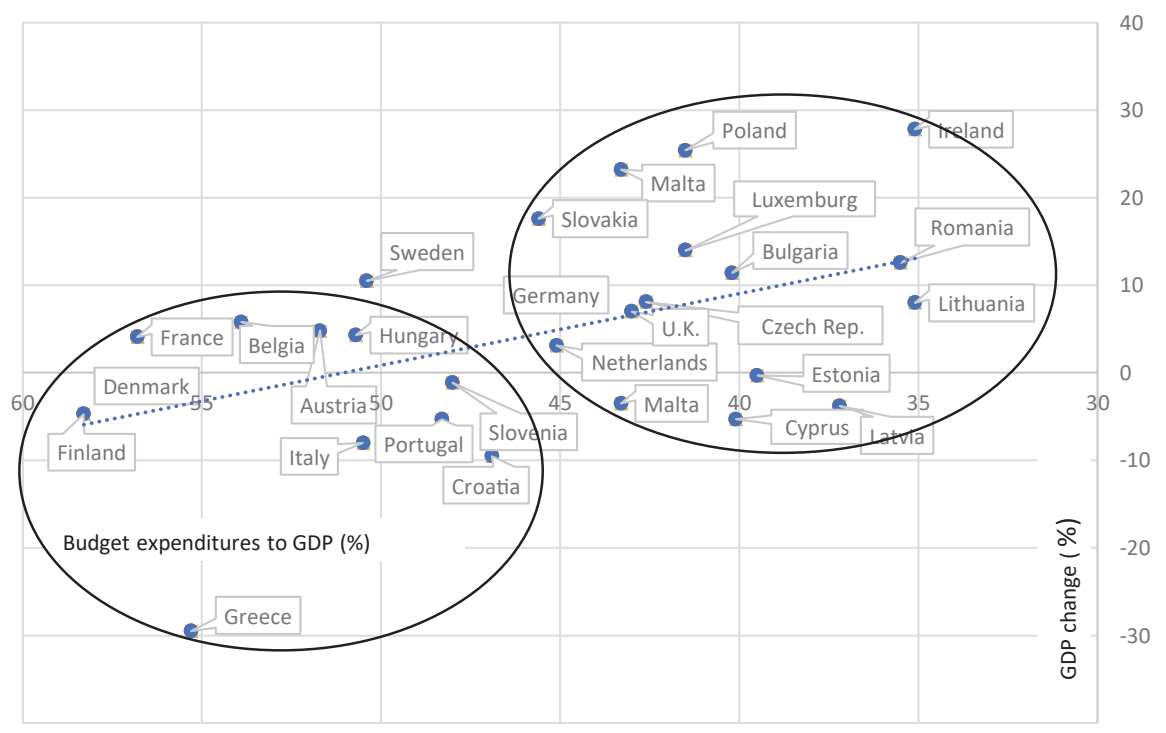

Figure 2. Budget expenditures (\%) in relation to GDP in 2015 and GDP change in 2008-2015 in EU states. Source: Own calculation based on Eurostat data [http://ec.europa.eu/Eurostat, access 18/06/2018].

It is worth considering the reasons for the differentiation in the level of indebtedness between EU states. As we can see, the nine most indebted EU states belong to the so-called old member states, and public debt was not reduced between 2008 and 2015 in any of these countries (see data in Annex 1). Additionally, five countries reached levels that make sustainable economic growth significantly more difficult. During the period considered, these countries achieved either negative economic growth or growth close to stagnation, not exceeding $1 \%$ point on average per year. Conversely, the 11 least indebted EU states are mainly the new member states, as well as Luxembourg, Denmark, and Sweden. The low level of debt of the new member states after the collapse of the Eastern Bloc and the much less developed social system are important factors affecting the different levels of debt of the new and old EU member states. At present, the level of GDP redistribution through the state budget is on average $6 \%$ points lower in the new member states than in the old member states, whereas the level of debt is $38 \%$ points lower in the former of these two groups. At the same time, it is worth emphasizing that despite the growing national debt of EU states, its average value in relation to GDP is still lower than that in the most developed economies of the world, Japan, and the United States (see data in Annex 2).

\section{Legal arrangements in place to reduce the macroeconomic imbalance}

The deepening debt crisis discussed in the previous section poses a significant risk to the stability of the economic and monetary union. This crisis resulted in the member states increasingly failing to comply 
with convergence conditions and led the EU to adopt legislation in November 2011, often referred to as the 'sixpack' due to the number of adopted regulations. The main objective of the measures taken was to reduce macroeconomic imbalance and ensure the proper functioning of national finances through preventive and corrective actions. According to Delivorias [2014], these provisions were intended to apply to all member states, although some (e.g. those regarding sanctions) should have applied only to euro area countries. The following regulations and directives were included in the sixpack ${ }^{1}$ :

- Regulation (EU) No. 1173/2011 of the European Parliament and of the Council of November 16, 2011, on the effective enforcement of budgetary surveillance in the euro area;

- Regulation (EU) No. 1174/2011 of the European Parliament and of the Council of November 16, 2011, on enforcement measures to correct excessive macroeconomic imbalances in the euro area;

- Regulation (EU) No. 1175/2011 of the European Parliament and of the Council of November 16, 2011, amending the Regulation (EC) No. 1466/97 on the strengthening of the surveillance of budgetary positions and the surveillance and coordination of economic policies;

- Regulation (EU) No. 1173/2011 of the European Parliament and of the Council of November 16, 2011, on the prevention and correction of macroeconomic imbalances;

- Council Regulation (EU) No. 1177/2011 of November 8, 2011, amending the Regulation (EC) No. 1467/97 on speeding up and clarifying the implementation of the excessive deficit procedure; and

- Council Directive 2011/85/EU of November 8, 2011, on requirements for budgetary frameworks of the member states.

According to Delivorias [2014], the purpose of the introduced legal acts was to

- cover the budgetary and economic policies with the European surveillance to ensure consistency in policy recommendations to member states;

- introduce an expenditure benchmark that would be linked to the country's medium-term budgetary objective, thus limiting the increase in annual government expenditure;

- enhance surveillance of countries by analyzing not only countries with current turnover deficits but also countries with current turnover surplus;

- allow the initiation of the excessive deficit procedure on the sole basis of the debt criterion, i.e. $60 \%$ of GDP;

- introduce a macroeconomic imbalance procedure, based on an early warning and enforcement system (this procedure would allow the Commission and the Council to launch a procedure requiring the country concerned to comply with a corrective action plan before imbalances become excessive);

- impose graduated financial sanctions, which could reach up to $0.5 \%$ of GDP.

The European Fiscal Compact, the Treaty on Stability, Coordination and Governance in the Economic and Monetary Union, entered into force on January 1, 2013. Its aim was to complement and strengthen the sixpack adopted earlier. The European Fiscal Compact was supplemented by the Regulation which entered into force on May 30, 2013, aimed at strengthening fiscal surveillance by adopting common rules for monitoring and assessing national budgetary plans. The Treaty was adopted by all EU states except the UK and Croatia, which did not ratify it after accession to the EU.

To assess the effectiveness of the sixpack and twopack systems, the European Commission conducted two economic reviews of the EU states by 2016. The first was published in February 2014 and concerned Regulation 472/2013, and the second was published in November 2014 and covered seven regulations (1173/2011, 1174/2011, 1175/2011, 1176/2011, 1177/2011, 472/2013, and 473/2013). The main objective of the second review was to determine 'to what extent the new rules introduced by the sixpack and the twopack have been effective in achieving their objectives and have contributed to progress in ensuring closer economic policy coordination and sustained convergence of member states' economic performances, while guaranteeing transparency, credibility and democratic accountability' of the European Commission [2014, p. 3].

1 http://eur-lex.europa.eu/legal-content/PL/ALL/?uri=0J:L:2011:306:TOC. 
In its report, the European Commission noted that the main problem in assessing the effectiveness of the implemented solutions was that it was a too short period since the introduction of the sixpack system (2011) and the twopack system (2013). As regards the evaluation of the effectiveness of the regulations, the Commission focused on three aspects:

- budgetary surveillance;

- macroeconomic imbalance procedure; and

- difficulties with financial stability in the euro area states.

\subsection{Assessment of budgetary surveillance}

The main reason for the introduction of fiscal surveillance was excessive deficit and debt levels in the member states. Fiscal surveillance introduced the concept of a significant deviation from the medium-term budgetary objective. In the euro area, the possibility of imposing financial sanctions in the case of such a derogation was introduced. The concept of expenditure benchmarks was also introduced to provide clear operational guidance to member states to help them plan their budgets. In the economic situation review, the Commission assessed the strengthened fiscal surveillance framework as effective. This surveillance has contributed to the consolidation of public finances. Most countries have met their medium-term budgetary objectives, and the number of countries under the excessive deficit procedure decreased from 23 in 2011 to 11 in 2014 and to 6 in May 2016. In turn, during the period under examination by the Commission, an average budget deficit of the EU-28 decreased from 4.5\% of GDP in 2011 to a value close to 3\% of GDP in 2014. The EU-28 budget deficit figures for 2015 , already at only $2.4 \%{ }^{2}$, are a strong confirmation of the successful consolidation of public finances. According to the European Commission [2014], the quality of annual budgets and medium-term budget planning has significantly improved.

\subsection{Assessment of macroeconomic imbalance procedure}

The new procedure has extended the surveillance of economic policies beyond budgetary issues and presently it concerns (i) external imbalances, (ii) competitiveness, (iii) asset prices, as well as (iv) internal and external debts. The new regulations (1174/2011 and 1176/2011) provide a framework for the detection, prevention, and correction of macroeconomic imbalances. During the period under review, the Commission has produced 42 in-depth reviews as the main element of the procedure regarding macroeconomic imbalances. In the years 2013 and 2014, the Commission identified excessive imbalances in four countries (Spain, Slovenia, Italy, and Croatia) but did not submit a proposal for their official identification by the Council, which resulted in the excessive imbalances procedure not being triggered. According to the European Commission [2014, pp. 7-9], the reform programs proposed by these countries were appropriate to the imbalances identified.

\subsection{Assessment of financial stability in euro area states}

At the entry into force of the European Fiscal Compact, financial assistance related to the macroeconomic adjustment program was provided to four euro area member states: Greece, Ireland, Portugal, and Cyprus. Spain, however, only requested financial assistance to capitalize financial institutions. According to the European Commission [2014, pp. 9-11], these countries have made a significant progress in reducing their budget deficits and their total public debt is stabilizing. The situation of member states in the context of the Macroeconomic Imbalance Procedure is summarized in Table 1. When assessing the effectiveness of the measures taken by the EU institutions during the financial crisis, and in particular the adoption of the sixpack legislation and the Fiscal Stability Treaty, attention should be paid to reducing the number

2 Data for 2015 from Eurostat [https://www.ec.europa.eu/Eurostat]. 
of countries in the excessive deficit procedure from the initial 11 to just one country, as of March 2018. Undoubtedly, reducing budget deficits below $3 \%$ is a step in the right direction. However, this is only a preliminary step toward debt reduction. It should be remembered that every budget deficit generates debt, even if it does not exceed 3\%.

Table 1. The situation of member states in the context of the Macroeconomic Imbalance Procedure in 2017 (EU Commission opinion from March 2018)

\begin{tabular}{ll}
\hline Procedure category & Member states \\
\hline Lack of economic imbalance & $\begin{array}{l}\text { Austria, Belgium, Denmark. Estonia, Lithuania, Luxemburg, Latvia, Malta, Poland, Czech } \\
\text { Republic, Romania, Slovakia, Hungary, United Kingdom, Finland, Slovenia }\end{array}$ \\
Economic imbalance & $\begin{array}{l}\text { Spain, Ireland, the Netherlands, Germany, Sweden, Bulgaria, France, Portugal } \\
\text { Excessive economic imbalance }\end{array}$ \\
\hline
\end{tabular}

Source: http://europa.eu/rapid/press-release_IP-18-1341_pl.htm (access 7/07/2018).

Only when a budget surplus is reached, it will be possible to reduce it gradually in the long term. According to Collignon [2013], the minimum level of fiscal consolidation should take into account the ratio of interest paid on debt to the total debt, which should not be higher than the amount of economic growth. Otherwise, there will be a permanent increase in the national debt. Despite adopting solutions making it possible to impose financial penalties on countries with excessive deficits, as of May 2016, the Commission had not taken such a step. Of course, the question arises to what extent potential financial sanctions in the form of an interest-bearing deposit of $0.2 \%$ of GDP are an effective mechanism to discourage deficit and debt reduction. Unfortunately, it is quite easy to imagine a situation in which a government planning a budget with excessive deficits is able to include an additional $0.2 \%$ as potential penalties.

The debt levels of EU member states, as well as their growth rates in 2008-2014, were higher than those of most non-EU OECD countries. Debt increased on average in non-EU OECD countries by $16 \%$ over the analyzed period, in old EU member states by $66 \%$, and in new EU member states by $87 \%$. Despite the highest debt growth rates in the new member states, the debt-to-GDP ratio is still at its lowest: $58 \%$ compared to $77.9 \%$ in non-EU OECD countries and as much as $95 \%$ in the old EU member states. It is worth noting here that debt at the level of $95 \%$ before the crisis occurred only in the Greek and Italian economies, but today this level or a greater one occurs in as many as eight countries (cf. data from Annex 1). The abovementioned figures show the scale of the problem, which has so far not been solved ${ }^{3}$. While at the beginning of the financial crisis, the most indebted Greek and Italian economies accounted for approximately $12 \%$ of EU GDP and less than $1.54 \%$ of Greece GDP, today the percentage of GDP produced by the most indebted countries is close to $40 \%$ of EU GDP. After the UK leaves the EU, it will be close to $50 \%{ }^{4}$. This means that currently almost half of the EU economy is chronically indebted and has little growth potential. A problem that cannot be ignored is the rising cost of servicing the debt, despite the relatively low cost of money associated with the very low level of interest rates of the European Central Bank (ECB). In the EU countries with the highest debt-to-GDP ratio, the annual cost of debt interest in relation to government revenue in 2015 was $10.41 \%$ in Portugal, 8.73\% in Italy, 8.01\% in Spain, 7.92\% in Greece, and 7.29\% in Cyprus ${ }^{5}$. After a period of deflation or very low inflation, the cost of debt servicing is expected to increase. These basic figures show the scale of the problem still faced by the EU and, in particular, the euro area, to which all of the most indebted countries belong.

3 A detailed classification of countries most affected by the global crisis based on other macroeconomic variables can be found in Dzikowska [2015].

4 Calculation based on http://ec.europa.eu/eurostat/data/database, access 18/06/2018.

5 Calculation based on http://ec.europa.eu/eurostat/data/database, access 18/06/2018. 


\section{Discretionary fiscal policy}

\subsection{European Economic Recovery Plan}

Discretionary fiscal policy, as already indicated in the first subsection, is an important tool to reduce negative effects of financial crises. For EU member states, and in particular for the euro area, it is in principle the most important tool available to manage potential crises, mainly due to the lack of the possibility of running a separate monetary policy. This subsection focuses on the analysis of two aspects of fiscal policy in the EU states after 2008. The first aspect is the implementation of the European Economy Recovery Plan (EERP) and the second aspect is changing fiscal policy in terms of amending the structure of taxation ${ }^{6}$. The scale of the EERP was unprecedented in the economic history of the European countries to date and in principle can only be compared to the Paulson Plan (Emergency Economic Stabilization Act of 2008 (EESA)), implemented in the United States in the same period, but primarily aimed at financial institutions. The fiscal stimulus under the EERP was planned to amount to EUR 200 billion, financed at the level of EUR 170 billion directly by the member states, with the remaining EUR 30 billion to come from the EU funds (in broad terms, the European Commission [2011]). The legal basis for the plan was Article 107(3)(b) Treaty on the Functioning of the European Union (TFEU), under which the EU states may implement 'aid to carry out projects of general European interest or to remedy a serious disturbance in the economy of any Member State.' The following instruments of government assistance to enterprises were implemented under the EERP:

- direct recapitalization;

- government guarantees on loans;

- loans at reduced interest rates;

- export credit insurances;

- investment in ecological production; and

- incentives to invest in company shares.

The EC approved government aid in 22 countries, of which only 19 took it up. The aid was mainly targeted at small- and medium-sized enterprises and could not exceed EUR 500,000. An exception was made for the automotive sector, which received $25 \%$ of all aid granted to enterprises; this aid was targeted at six automotive companies: Ford, Volvo, Saab, Opel, Peugeot and Renault. The figures in Annex 3 are a summary of the approved aid per country and its actual use. It is clear that the final amount of EUR 36.4 billion of aid used was significantly lower than the original target by the EERP of EUR 200 billion.

\subsection{Changes in the structure of taxation}

Summary of basic changes in the structure of taxation, i.e. changes in tax rates made in the EU states in the years 2008-2015, is presented in Table 2. These data show a clear trend of increasing indirect tax rates, i.e. value-added tax (VAT), with a simultaneous reduction in the direct tax rates of corporate income tax (CIT) and personal income tax (PIT), mainly in the new member states. However, these changes can be considered as a clear trend toward a shift of the burden from direct to indirect taxation. An increase in VAT rates during an economic crisis is quite easy to justify by its easy collectability and the difficulty of

\footnotetext{
6 The study deliberately omitted the analysis of financial assistance to the financial sector. Between October 2008 and October 2014, the Commission issued more than 450 decisions authorizing government support to the financial sector. The Commission authorized (i) provision of guarantees of EUR 4.3 trillion, of which EUR 906 billion (21\%) was actually provided and only USD 3.3 billion was utilized; (ii) financing of financial sector capitalization at the level of EUR 1.5 trillion, of which EUR 636 billion (43\%) was used; and (iii) the value of guarantees in the form of government aid of only EUR 387 billion in 2013. The main objective of the financial assistance provided was to increase confidence in the financial sector.
} 
avoidance compared to direct taxes. At this point, it is worth noting that no country in the EU has reduced VAT since 2008, and as many as 20 countries have increased it ${ }^{7}$.

Conversely, the reasons for the reduction in CIT rates can be seen in two areas: global tax competition and competition within the EU. In both cases, the governments compete in attracting foreign investors, i.e. creating favorable conditions for locating foreign direct investment in a given country [Wilinski, 2013, pp. 90-91]. In addition, as far as intra-EU competition is concerned, it is worth noting that there is a significant difference in CIT rates between the new and old EU member states, with median CIT rates of $19 \%$ and $28 \%$, respectively, which gives a difference of $9 \%$ points. Owing to the competitive rates in the new member states, the countries of Western and Southern Europe have been forced to reduce their CIT rates. A very good example of this is the reduction in CIT in Austria, even before the financial crisis, from $34 \%$ in 2004 to $25 \%$ in 2005.

Table 2. Changes in VAT, PIT, and CIT rates in 2008-2015 (data for EU member states)

\begin{tabular}{|c|c|c|c|}
\hline Country & VAT & PIT & CIT \\
\hline Austria & - & - & - \\
\hline Belgium & - & - & - \\
\hline Bulgaria & - & - & - \\
\hline Croatia & $\pi$ & ע & - \\
\hline Cyprus & $\pi$ & $\pi$ & $\pi$ \\
\hline Czech Rep. & $\pi$ & $\pi$ & ע \\
\hline Denmark & - & ע & ע \\
\hline Estonia & $\pi$ & ע & $y$ \\
\hline Finland & $\pi$ & $\pi$ & $y$ \\
\hline France & $\pi$ & $\pi$ & $\pi$ \\
\hline Germany & - & - & - \\
\hline Greece & $\pi$ & $\pi$ & ע \\
\hline Hungary & $\pi$ & ע & $y$ \\
\hline Ireland & $\pi$ & $\pi$ & - \\
\hline Italy & $\pi$ & $\pi$ & - \\
\hline Latvia & - & ע & - \\
\hline Lithuania & $\pi$ & ע & - \\
\hline Luxemburg & $\pi$ & $\pi$ & ע \\
\hline Malta & - & - & - \\
\hline Netherlands & $\pi$ & - & ע \\
\hline Poland & $\pi$ & ע & - \\
\hline Portugal & $\pi$ & $\pi$ & $\pi$ \\
\hline Romania & $\pi$ & 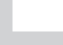 & - \\
\hline Slovakia & $\pi$ & $\pi$ & $\pi$ \\
\hline Slovenia & $\pi$ & $\pi$ & ע \\
\hline Spain & $\pi$ & $\pi$ & ע \\
\hline Sweden & - & $\pi$ & ע \\
\hline UK & $\pi$ & $\pi$ & ע \\
\hline
\end{tabular}

Source: Own calculation based on Eurostat, Taxation trends in the European Union. Data for the EU member states, Iceland and Norway, DG Taxation and Customs Union, Luxemburg 2015.

The reason for this action by the Austrian government was the 2004 accession of the new member states neighboring Austria: the Czech Republic (28\% CIT), Slovakia (19\% CIT), and Hungary (17.6\% CIT) [Eurostat, 2015]. It should be remembered, however, that the decisions of the governments of the old member states

7 In total, the VAT rate was increased in 22 countries, but in Romania and Latvia, the increase was only temporary, and the VAT rate is currently no higher in both countries than that in 2008. 
are taken not because they fear the relocation of production but to create more favorable conditions for development of local businesses. Taking into account the abovementioned reasons, it does not seem entirely clear what guided the French government to raise the already high CIT rate to $38 \%$ during the financial crisis while raising the VAT rate by only $0.4 \%$ points to $20 \%$.

The analysis of the changes carried out in the tax rates of both direct and indirect taxes should also take into account the impact of each of these taxes on the structure of the state budget revenue. As already mentioned, there is now a clear trend in EU countries toward gradually increasing the importance of indirect tax revenues, while the importance of direct tax revenues is declining. Such an analysis is even more interesting if we compare the policies of individual governments in this area in the new and old member states. As shown in Annex 5, in the vast majority of the new member states, the share of revenue generated by indirect taxes is higher than in the old member states.

Such a fiscal policy in new EU member states allows for the application of lower direct tax rates, which, as has already been mentioned, is particularly important in the case of the amount of CIT and its impact on the location of foreign investments, as well as on the rate of domestic capital accumulation. It is worth noting that there is currently global tax competition in the area of corporate taxation. Therefore, the objective of the tax policy of the new member states is not to compete with the old member states but above all to meet global competition, which the old member states should also remember.

France and Belgium are the only EU states with debt exceeding 90\% of GDP and at the same time with the highest CIT rates (38\% and 34\%, respectively, see data in Annex 4). At the same time, these countries have the lowest budget revenues from indirect taxes and relatively low VAT rates of $20 \%$ and $21 \%$, respectively. In the context of the analysis of changes in fiscal policy that are taking place in EU countries, and in particular taking into account the change in the structure of budget revenues, it would be advisable in both countries to increase VAT rates and, at the same time, to reduce CIT rates.

\section{Summary}

One of the main problems of democratic systems is the dependence of political parties on voters. This leads to an increase in the role of the state in the economy and the distribution of privileges to various social groups. The result of such a policy is an increase in the redistribution of GDP through the budget and also often an increase in the deficit and, consequently, the debt of a country. The social resistance encountered between 2008 and 2015 in an attempt to reduce social benefits in Greece, Spain, and France clearly shows that the granting of benefits is much easier than their reduction. This is particularly relevant in the context of the basic conclusions of this study:

- The debt levels of the EU member states and their growth rates in 2008-2014 were higher than those of most non-EU OECD states.

- Despite the legal solutions introduced by the Council and the European Commission in the form of the sixpack and the European Fiscal Compact, as well as the discretionary fiscal measures taken, including the European Economic Recovery Plan, five EU states (Cyprus, Greece, Italy, Portugal, and Spain) are facing a permanently worsening level of public debt.

- In order to reduce the level of public debt and achieve satisfactory economic growth in the most indebted EU countries, deep reforms are needed to the structure and level of government expenditure.

- When assessing the effectiveness of the sixpack and the Fiscal Treaty legislative measures adopted by the EU institutions during the financial crisis, attention should be paid to reducing the number of countries in excessive deficit procedures from 11 to six.

- As regards discretionary fiscal policies, in particular as a result of changes in VAT and CIT rates, there is a clear trend in EU states to reduce direct tax revenues and increase indirect tax revenues. Such a change in the structure increases the tax competitiveness of EU states on a global scale. 
Annex 1. Indebtedness level and government expenditures in relation to GDP in 2015 year and GDP change in 2008-2015 (data for EU member states in percentage)

\begin{tabular}{|c|c|c|c|}
\hline Country & Debt-to-GDP ratio in 2015 & Government expenditures as GDP percentage & GDP changes in 2008-2015 \\
\hline Estonia & 9.7 & 39.5 & -0.3 \\
\hline Luxemburg & 21.4 & 41.5 & 14.0 \\
\hline Bulgaria & 26.7 & 40.2 & 11.4 \\
\hline Latvia & 36.4 & 37.2 & -3.8 \\
\hline Romania & 38.4 & 35.5 & 12.6 \\
\hline Denmark & 40.2 & 55.7 & -1.0 \\
\hline Czech Rep. & 41.1 & 42.6 & 8.1 \\
\hline Lithuania & 42.7 & 35.1 & 8.0 \\
\hline Sweden & 43.4 & 50.4 & 10.5 \\
\hline Poland & 51.3 & 41.5 & 25.4 \\
\hline Slovakia & 52.9 & 45.6 & 17.6 \\
\hline Finland & 63.1 & 58.3 & -4.7 \\
\hline Malta & 63.9 & 43.3 & 23.2 \\
\hline Netherlands & 65.1 & 45.1 & 3.1 \\
\hline Germany & 71.2 & 43.9 & 7.6 \\
\hline Hungary & 75.3 & 50.7 & 4.3 \\
\hline Slovenia & 83.2 & 48.0 & -1.1 \\
\hline Austria & 86.2 & 51.7 & 4.8 \\
\hline Croatia & 86.7 & 46.9 & -9.5 \\
\hline United Kingdom & 89.2 & 43.0 & 7.0 \\
\hline Ireland & 93.8 & 35.1 & 27.8 \\
\hline France & 95.8 & 56.8 & 4.1 \\
\hline Spain & 99.2 & 43.3 & -3.5 \\
\hline Belgium & 106.0 & 53.9 & 5.8 \\
\hline Cyprus & 108.9 & 40.1 & -5.3 \\
\hline Portugal & 129.0 & 48.3 & -5.3 \\
\hline Italy & 132.7 & 50.5 & -8.0 \\
\hline Greece & 176.9 & 55.3 & -29.5 \\
\hline
\end{tabular}

Source: Own calculation based on Eurostat [http://ec.europa.eu/Eurostat, access 18/04/2018].

Annex 2. Indebtedness level as a percentage of GDP in OECD countries (data for 2008 and 2014)

\begin{tabular}{llll}
\hline Country & $\mathbf{2 0 0 8}$ & $\mathbf{2 0 1 4}$ & (\%) \\
\hline Old EU member states & & & \\
Luxembourg & 18.0 & 27.3 & 52 \\
Sweden & 41.8 & 48.1 & 15 \\
Denmark & 32.3 & 49.4 & 53 \\
Germany & 41.8 & 53.5 & 28 \\
Finland & 32.5 & 59.9 & 85 \\
Netherland & 53.8 & 72.9 & 35 \\
Austria & 68.1 & 92.6 & 36 \\
France & 64.7 & 98.0 & 51 \\
Spain & 37.1 & 102.4 & 176 \\
United Kingdom & 55.4 & 108.0 & 95 \\
Belgium & 90.3 & 112.0 & 24 \\
Ireland & 46.7 & 122.4 & 162 \\
Italy & 103.1 & 146.7 & 42 \\
Portugal & 80.2 & 150.2 & 87 \\
Greece & 126.1 & 181.6 & 44 \\
Average value & 59.5 & 95.0 & 66 \\
New EU member states & & & \\
Estonia & 5.1 & 10.1 & 96 \\
Latvia & 25.9 & 43.8 & 69 \\
\hline
\end{tabular}


Annex 2. Continued

\begin{tabular}{llll}
\hline Country & $\mathbf{2 0 0 8}$ & $\mathbf{2 0 1 4}$ & (\%) \\
\hline Czech Republic & 30.5 & 52.0 & 70 \\
Poland & 50.2 & 53.0 & 6 \\
Slovakia & 32.8 & 58.0 & 77 \\
Slovenia & 26.7 & 94.0 & 253 \\
Hungary & 71.1 & 97.7 & 37 \\
Average value & $\mathbf{3 4 . 6}$ & $\mathbf{5 8 . 4}$ & $\mathbf{8 7}$ \\
OECD countries (no EU members) & & \\
Norway & 43.5 & 18.0 & -59 \\
Turkey** & 54.0 & 40.6 & -25 \\
Australia & 22.1 & 44.8 & 103 \\
Canada & 42.4 & 47.5 & 12 \\
Mexico & 44.0 & 49.9 & 13 \\
Israel & 103.4 & 92.9 & -10 \\
United States & 64.0 & 97.1 & 52 \\
Iceland*** & 85.7 & 103.2 & 20 \\
Japan & 147.3 & 207.4 & 41 \\
Average value & 67.4 & $\mathbf{7 7 . 9}$ & $\mathbf{1 6}$ \\
\hline
\end{tabular}

* OECD statistics are not available for Chile, South Korea, and Switzerland.

** For Turkey, the data are for 2009 instead of 2008.

*** The last available data for Iceland are of 2013.

Source: OECD [http://stats.oecd.org/access: 31/06/2018].

Annex 3. State aid in EU granted for enterprises in 2009-2012 (in billion EUR)

\begin{tabular}{lll}
\hline & Aid approved & Aid realized \\
\hline EU-27 & 82.9 & 36.4 \\
Germany & 29.6 & 17.7 \\
Austria & 10.2 & 1.8 \\
UK & 10.1 & 0.6 \\
Hungary & 9.7 & 0.3 \\
Belgium & 8.1 & 0.8 \\
Greece & 4 & 0.6 \\
Spain & 2.5 & 0.7 \\
Slovenia & 1.3 & 1.5 \\
Sweden & 1.3 & 1.1 \\
Czech Republic & 1.1 & 0.4 \\
Portugal & 0.8 & 0.8 \\
Latvia & 0.6 & 0.2 \\
France & 0.6 & 6.2 \\
Luxemburg & 0.5 & 0.6 \\
Finland & 0.5 & 0.9 \\
Romania & 0.4 & 0.4 \\
Slovakia & 0.4 & 0 \\
Italy & 0.4 & 1 \\
Ireland & 0.4 & 0.4 \\
Poland & 0.2 & 0 \\
Estonia & 0.2 & 0 \\
Lithuania & 0.1 & 0 \\
Malta & 0 & 0 \\
Bulgaria & 0 & 0 \\
Denmark & 0 & 0.2 \\
Netherlands & 0 & 0 \\
Cyprus & 0 & \\
\hline Sori & & \\
\hline
\end{tabular}

Source: EU Commission, State aid granted under the temporary framework [http://ec.europa.eu/competition/state_aid/ scoreboard/financial_economic_crisis_aid_en.html]. 
Annex 4. CIT and VAT rates in EU countries (data for 2016 in \%)

\begin{tabular}{|c|c|c|c|c|}
\hline \multirow[t]{2}{*}{ Country } & \multicolumn{2}{|r|}{ CIT } & \multicolumn{2}{|c|}{ PIT } \\
\hline & SME & Others & Maximum value & Minimum value \\
\hline \multicolumn{5}{|c|}{ New EU member states } \\
\hline Bulgaria & & 10 & 10 & 10 \\
\hline Lithuania & 5 & 15 & 15 & 15 \\
\hline Latvia & 9 & 15 & 23 & 23 \\
\hline Cyprus & & 12.5 & 35 & 20 \\
\hline Romania & & 16 & 16 & 16 \\
\hline Slovenia & & 17 & 50 & 16 \\
\hline Czech Republic & & 19 & 22 & 15 \\
\hline Poland & & 19 & 32 & 18 \\
\hline Croatia & & 20 & 40 & 12 \\
\hline Estonia & & 20 & 20 & 20 \\
\hline Hungary & 16 & 20.6 & 16 & 16 \\
\hline Slovakia & & 22 & 25 & 19 \\
\hline Malta & & 35 & 35 & 15 \\
\hline Average & & 18.5 & 26.1 & 16.5 \\
\hline Median & & 19 & 23 & 16 \\
\hline \multicolumn{5}{|c|}{ Old EU member states } \\
\hline Ireland & & 12.5 & 48 & 20 \\
\hline Finland & & 20 & 51.6 & 6.5 \\
\hline U.K. & & 20 & 45 & 20 \\
\hline Sweden & & 22 & 57 & 20 \\
\hline Denmark & & 23.5 & 55.8 & 8 \\
\hline Austria & & 25 & 50 & 36.5 \\
\hline Netherlands & & 25 & 52 & 36.5 \\
\hline Spain & 25 & 28 & 46 & 19.5 \\
\hline Greece & & 29 & 48 & 22 \\
\hline Luxemburg & & 29.2 & 43.6 & 0 \\
\hline Portugal & 17 & 29.5 & 56.5 & 14.5 \\
\hline Germany & & 30.2 & 50.5 & 14 \\
\hline Italy & & 31.4 & 48.9 & 23 \\
\hline Belgium & & 34 & 53.8 & 25 \\
\hline France & 15 & 38 & 50.3 & 14 \\
\hline Average & & 26.5 & 50.5 & 18.6 \\
\hline Median & & 28 & 50.3 & 20 \\
\hline
\end{tabular}

Source: Own calculation based on Eutostat, Taxation trends in the European Union. Data for the EU member states, Iceland and Norway, DG Taxation and Customs Union, Luxemburg 2015.

Annex 5. Income of indirect taxes as a percentage of governmental budget income in EU countries (data for 2015 in \%) and changes in VAT rates in 2008-2015

\begin{tabular}{|c|c|c|c|c|c|}
\hline Country & $\begin{array}{l}\text { Indirect taxes as a \% of govern- } \\
\text { mental budget income }\end{array}$ & $\begin{array}{l}\text { VAT as a \% of governmental } \\
\text { income }\end{array}$ & $\begin{array}{l}\text { VAT rates before } \\
\text { changes }\end{array}$ & $\begin{array}{l}\text { VAT rates in } \\
2016\end{array}$ & $\Delta$ \\
\hline Bulgaria & 54.0 & 33.0 & 20.0 & 20.0 & 0.0 \\
\hline Croatia & 52.0 & 35.0 & 23.0 & 25.0 & 2.0 \\
\hline Hungary & 49.0 & 23.0 & 25.0 & 27.0 & 2.0 \\
\hline Sweden & 49.0 & 20.0 & 25.0 & 25.0 & 0.0 \\
\hline Romania & 47.0 & 30.0 & 19.0 & 20.0 & 1.0 \\
\hline Cyprus & 44.0 & 24.0 & 17.0 & 19.0 & 2.0 \\
\hline Latvia & 43.0 & 26.0 & 21.0 & 21.0 & 0.0 \\
\hline Lithuania & 42.0 & 28.0 & 19.0 & 21.0 & 2.0 \\
\hline Estonia & 42.0 & 26.0 & 18.0 & 20.0 & 2.0 \\
\hline
\end{tabular}


Annex 5. Continued

\begin{tabular}{|c|c|c|c|c|c|}
\hline Country & $\begin{array}{l}\text { Indirect taxes as a \% of govern- } \\
\text { mental budget income }\end{array}$ & $\begin{array}{l}\text { VAT as a \% of governmental } \\
\text { income }\end{array}$ & $\begin{array}{l}\text { VAT rates before } \\
\text { changes }\end{array}$ & $\begin{array}{l}\text { VAT rates in } \\
2016\end{array}$ & $\Delta$ \\
\hline Slovenia & 40.0 & 23.0 & 20.0 & 22.0 & 2.0 \\
\hline Poland & 39.0 & 21.0 & 22.0 & 23.0 & 1.0 \\
\hline Malta & 39.0 & 23.0 & 18.0 & 18.0 & 0.0 \\
\hline Portugal & 37.0 & 22.0 & 20.0 & 23.0 & 3.0 \\
\hline Czech Republic & 37.0 & 21.0 & 19.0 & 21.0 & 2.0 \\
\hline UK & 37.0 & 20.0 & 15.0 & 20.0 & 5.0 \\
\hline Greece & 36.0 & 19.0 & 21.0 & 23.0 & 2.0 \\
\hline Ireland & 36.0 & 19.0 & 21.5 & 23.0 & 1.5 \\
\hline Denmark & 35.0 & 20.0 & 25.0 & 25.0 & 0.0 \\
\hline Slovakia & 35.0 & 21.0 & 19.0 & 20.0 & 1.0 \\
\hline Italy & 34.0 & 13.0 & 21.0 & 22.0 & 1.0 \\
\hline Finland & 33.0 & 21.0 & 22.0 & 24.0 & 2.0 \\
\hline Spain & 33.0 & 18.0 & 18.0 & 21.0 & 3.0 \\
\hline Austria & 33.0 & 18.0 & 20.0 & 20.0 & 0.0 \\
\hline France & 33.0 & 14.0 & 19.6 & 20.0 & 0.4 \\
\hline Luxemburg & 33.0 & 19.0 & 15.0 & 17.0 & 2.0 \\
\hline Netherlands & 31.0 & 18.0 & 19.0 & 21.0 & 2.0 \\
\hline Belgium & 28.0 & 14.0 & 21.0 & 21.0 & 0.0 \\
\hline Germany & 28.0 & 18.0 & 19.0 & 19.0 & 0.0 \\
\hline
\end{tabular}

Bruksela 2016, s. 1-24 oraz Eutostat, Taxation trends in the European Union. Data for the EU Member States, Iceland and Norway, DG Taxation and Customs Union, Luxemburg 2015.

* Latvia has changed the VAT rate for one year only in 2011 to the $22 \%$ level.

**In Romania, the VAT level during 2010-2015 was $24 \%$.

Source: Own calculation based on: European Commision, "VAT Rates Applied in the Member States of the European Union”

\section{Bibliography}

Barro, R. (1979), On the determination of the public debt, The Journal of Political Economy, Vol. 87, No. 5, part 1, pp. 940-971. Collignon, S. (2013), Austerity versus growth: fiscal policy and debt sustainability, Social Europe Journal.

Delivorias, A. (2014), Plenary Session 5/12/2014, European Parliament Analysis Office, Strasburg.

Dzikowska, M., Gorynia, M., Jankowska, B. (2015), Globalny kryzys gospodarczy - próba pomiaru efektów dla poszczególnych krajów, Ekonomista, $\mathrm{nr} 6$.

European Commission. (2011), The effects of temporary State aid rules adopted in the context of the financial and economic crisis, Commission Staff Working Paper, Brussels.

European Commission. (2013), COM (2014) 61, Communication from the commission to the European Parliament and the council on the application of Regulation (EU), No 472/2013.

European Commission. (2014), COM (2014) 905, Opinion of the European Economic and Social Committee on the 'Communication from the Commission to the European Parliament, the Council, the European Central Bank, the European Economic and Social Committee and the Committee of the Regions - Economic governance review - Report on the application of Regulations (EU) No 1173/2011, (EU) No 1174/2011, 1175/2011, 1176/2011, 1177/2011, 472/2013 and 473/2013, Brussel.

European Commission. (2016a), Press release Spring 2016 European semester package: commission issues country specific recommendations, Brussels.

European Commission. (2016b), VAT rates applied in the Member States of the European Union, Brussels.

Eurostat. (2015), Taxation trends in the European Union. Data for the EU Member States, Iceland and Norway, DG Taxation and Customs Union, Luxemburg.

Hebous, S. (2009), The effects of discretionary fiscal policy on macroeconomic aggregates: a reappraisal, Goethe University Frankfurt, Frankfurt.

Reinhart, C., Rogoff K. (2010), Growth in a time of debt, American Economic Review Papers and Proceedings.

Trichet, J.C. (2013), International policy coordination in the Euro area: toward an economic and fiscal federation by exception, Journal of Policy Modeling, Vol. 35, pp. 473-481.

Wilinski, W, (2013), Internationalization of central and eastern European countries and their firms in the global crisis, in: M. Marinov, S. Marinova, (Eds), Emerging economies and firms in the global crisis, Palgrave Macmillan. 


\section{Statistical and law data bases}

Eurostat: http://ec.europa.eu/eurostat/data/database Europa Lex: http://eur-lex.europa.eu/legal-contentPL OECD statistics: http://stats.oecd.org/

\section{Legal acts}

- Regulation (EU) No. 1173/2011 of the European Parliament and of the Council of November 16, 2011, on the effective enforcement of budgetary surveillance in the euro area;

- Regulation (EU) No. 1174/2011 of the European Parliament and of the Council of November 16, 2011, on enforcement measures to correct excessive macroeconomic imbalances in the euro area;

- Regulation (EU) No. 1175/2011 of the European Parliament and of the Council of November 16, 2011, amending the Regulation (EC) No. 1466/97 on the strengthening of the surveillance of budgetary positions and the surveillance and coordination of economic policies;

- Regulation (EU) No. 1173/2011 of the European Parliament and of the Council of November 16, 2011, on the prevention and correction of macroeconomic imbalances;

- Council Regulation (EU) No. 1177/2011 of November 8, 2011, amending the Regulation (EC) No. 1467/97 on speeding up and clarifying the implementation of the excessive deficit procedure;

- Council Directive 2011/85/EU of November 8, 2011, on requirements for budgetary frameworks of the member states;

- The Treaty on the Functioning of the European Union (TFEU); and

- The Treaty on Stability, Coordination and Governance in the Economic and Monetary Union.

\section{Internet sources}

European Central Bank: https://www.ecb.europa.eu/mopo/eaec/fiscal/html/index.en.html http://www.debtclocks.eu/eu-ranking-expenditure-on-interest-payments-in-percent-of-governmentrevenue.html 